\title{
Attitude, Smoking Behavior, and Physical Activities Toward Diabetes Mellitus-Pulmonary Tuberculosis
}

\author{
Retno Lian Afidah ${ }^{1)}$, Muhammad Atoillah Isfandiari ${ }^{2)}$ \\ ${ }^{1}$ Sidoarjo Health Office, Street of Mayjend Sungkono Number 46, Pucang, Sidoarjo, Indonesia \\ ${ }^{2}$ Universitas Airlangga Health Services Centre, Street of Airlangga 4-6 Surabaya, Indonesia \\ Email: retnolian@gmail.com
}

\begin{abstract}
Background: Every year an average of 9 million people suffer from Tuberculosis and about 2 million people die every year in the world. The Behavior Area is divided into attitudes and actions. Purpose: The purpose of this study was to analyze the relationship between attitude, smoking behavior, physical activity and the incidence of Diabetes Mellitus-pulmonary Tuberculosis. Method: This study was an observational analytic study using a case control matching design. The research sample is 30 case samples and 30 control samples. Results: From the results of the Chi Square analysis, it is known that there is a significant relationship that is the attitude towards pulmonary Tuberculosis disease and physical activity towards pulmonary Tuberculosis $(p<0.05)$ and there is no significant relationship ( $p>0.05)$ between smoking behavior towards Pulmonary of Diabetes Mellitus-pulmonary Tuberculosis. Odds Ratio of this study is the attitude towards pulmonary Tuberculosis disease of 3.455 and physical activity of 9.036. Conclusion: the attitude of patients with Diabetus Mellitus towards Pulmonary Tuberculosis and physical activity of patients with Diabetus Mellitus risked the incidence of Pulmonary Tuberculosis.
\end{abstract}

Keywords: smoking, pulmonary $T B$, diabetes mellitus

\section{INTRODUCTION}

Tuberculosis (TB) is still a global health problem. Morbidity and mortality due to TB has decreased, however in 2014 around 1.2 million of the 9.6 million TB patients died. India, Indonesia and China are the top three countries in the world that have the most TB sufferers, namely $23 \%, 10 \%$ and $10 \%$ (WHO, 2015).

East Java Province ranks second in Indonesia in the number of new cases of TB sufferers. Surabaya City is still the city with the most TB sufferers in East Java (Dinkes Kota Surabaya, 2015).

Diabetes Mellitus (DM) sufferers in the world continue to increase in number every year, from the latest WHO data it is known that in 2000 that amounted to 150 million people in the world affected by $D M$. The number of sufferers of this disease has also increased in developing countries and one of them is the State of Indonesia (WHO, 2014).

Increased prevalence of DM sufferers is also accompanied by an increased prevalence of pulmonary TB sufferers. DM patients have a risk of two to three greater suffer from pulmonary TB disease compared with patients who do not suffer from DM. DM influences chemotaxis, phagocytosis, and antigen presenting by phagocytes. Mycobacterium tuberculosis elimination defects can occur due to lack of activation of pulmonary TB alveolar macrophages with DM so that it can reduce the interaction of $\mathrm{T}$ cell lymphocytes to macrophages. DM sufferers are more often exposed to pulmonary TB infection because of host defense mechanisms and defects in the function of immune cells (Wijaya, 2015).

Based on the form of response to stimulus, the behavior can be grouped into closed behavior and open behavior. Closed behavior is a person's response to a stimulus in a closed or veiled form. This reaction is limited to the attention, knowledge, perception, awareness, and attitude that occurs in the person who receives the stimulus so that it has not been clearly observed by others. Open behavior is a person's response to a stimulus in the form of real action or open 
action. The response to the stimulus is in the form of an action or practice so that it can be easily observed by others (Notoatmodjo, 2010).

Research in Korea shows that DM sufferers who smoke \pm one pack of cigarettes a day have a high risk of death from TB. Diabetes and smoking each increase the risk of death in the first 12 months of treatment. Estimated combined effects of diabetes and smoking have an Odd Ratio of 5.78 (Reed et al., 2013).

The tendency of increasing proportion of Indonesian population aged over 15 years who have smoking and chewing tobacco behavior based on Riskesdas 2007, 2010 and 2013 surveys is $34.2 \%, 34.7 \%, 36.3 \%$. The same figure is also found in the province of East Java at 33.3\% (Kemenkes RI, 2013).

The 2013 Riskesdas data states that $26.1 \%$ of Indonesia's population with physical activity categories are less active. Twenty-two provinces of all provinces in Indonesia are included in provinces with less active activities which have above average proportions, the large proportion for East Java province is $33.9 \%$.

MET or metabolic equivalent is a standard unit used to estimate the amount of oxygen used by the body during physical activity. 1 MET is the energy or oxygen used by the body at rest, sitting still or reading a book. The harder your body works during activities or during activities, the more oxygen is consumed and the higher the MET level (Badan Penelitian dan Pengembangan Kesehatan, 2013).

In Surabaya Lung Hospital the number of DM sufferers with TB in 2013 was 27 out of 252 DM patients, in 2014 the number of DM sufferers with TB increased by 43 of 122 patients and in 2016 there was an increase of 54 patients out of 488 cases. Pulmonary DM-TB is a disease whose incidence is increasing which causes high morbidity and mortality rates. Based on the above background, researchers intend to see the relationship between attitudes, physical activity and smoking habits as risk factors for pulmonary DM-TB.

\section{METHOD}

This research is an observational analytic study using case control matching design. The population used for this study were DM patients at the Lung Hospital in Surabaya who were over 18 years old. The case population in this study was DM patients who visited the Lung Hospital in Surabaya accompanied by pulmonary TB complications. The control population for this study was DM patients who visited the Lung Hospital in Surabaya without a history of pulmonary TB disease.

The total sample size was 60 samples. The sample is divided into 30 samples for the case group and 30 samples for the control group. The sample was a portion of DM patients found in the Lung Hospital in Surabaya in December 2016 to February 2017. The case sample was DM patients who visited the Lung Hospital in Surabaya with age over 18 years and suffered from pulmonary TB while the control sample was a patient DM who visited the Lung Hospital in Surabaya aged 18 years and over who did not suffer from pulmonary TB.

The research sampling method is the total sampling method. The method is used for case group samples and for the control sample, age, sex and body mass index (BMI) were adjusted. This research was conducted in December 2016 until February 2017 at the Lung Hospital in Surabaya. This location was chosen because of the high number of DM sufferers from year to year and is an outpatient referral hospital for pulmonary TB patients. The independent variables used in this study were the attitude of DM sufferers about pulmonary TB disease, smoking habits, physical activity and the occurrence of pulmonary DM-TB as the dependent variable.

This research has been through ethical tests conducted by the Airlangga University Ethics Commission Team. This study uses primary data obtained through questionnaire answers. The questionnaire examines attitudes, physical activity and smoking behavior. Questionnaires for assessing physical activity were adopted from IPAQ.

This study uses secondary data obtained by looking at DM patient visit data at Surabaya Lung Hospital in Lung Poly 1 and Internal Medicine Poly. The completion of the questionnaire in this study was to conduct interviews with patients after DM patients were examined by a doctor. Before the data of this study 
were obtained, the researcher explained first the matters relating to the study, after that it provided an information sheet of concern for DM patients. Each variable is analyzed using certain analysis techniques. Univariable analysis in this study uses the frequency distribution related to variables so that we get a description of the characteristics of each variable that exists.

Bivariable analysis is used to determine the significance of the dependent and independent variables and the relationship between the two. Bivariate analysis is done in analyzing the relationship between the independent variable and the dependent variable. The analysis was performed by Chi Square test with significance $p<0.05$. Related risk factors can be determined from the calculation of Odd Ratio using $95 \% \mathrm{Cl}$. The risk of developing pulmonary TB can be seen in the exponent section of the test.

\section{RESULTS AND DISCUSSION}

The results of the analysis of the relationship of attitudes, smoking behavior and physical activity to the incidence of pulmonary DM-TB using the Chi Square test are described in table 1. The results based on table 1 show that based on the attitude of DM sufferers about pulmonary TB, the case group and the control group were positive at $16.7 \%$ and $31.7 \%$. Based on the smoking behavior variable, respondents for the case group and the control group that mostly did not have smoking behavior were $43.3 \%$ and $54.0 \%$. Based on physical activity variables, case group and control group respondents had a high activity level of $13.3 \%$ and $38.3 \%$.

Table 1. Relationship between the Attitude of DM Sufferers about Pulmonary TB, Smoking Behavior, Physical Activity towards the Occurrence of Pulmonary TB in the Lung Hospital in Surabaya in 2017

\begin{tabular}{|c|c|c|c|c|c|c|c|}
\hline \multirow{3}{*}{ Variables } & \multicolumn{4}{|c|}{ Group } & \multicolumn{3}{|c|}{ Score } \\
\hline & \multicolumn{2}{|c|}{ Case } & \multicolumn{2}{|c|}{ Control } & \multirow{2}{*}{$P$ Value } & \multirow{2}{*}{ OR } & \multirow{2}{*}{$\mathrm{Cl} 95 \%$} \\
\hline & $\mathbf{n}$ & $\%$ & $\mathbf{n}$ & $\%$ & & & \\
\hline \multicolumn{8}{|l|}{ Attitude } \\
\hline Negative & 20 & 33,3 & 11 & 18,3 & \multirow{2}{*}{0,039} & \multirow{2}{*}{3,455} & \multirow{2}{*}{$(1,191<\mathrm{OR}<9,990)$} \\
\hline Positive & 10 & 16,7 & 19 & 31,7 & & & \\
\hline \multicolumn{8}{|l|}{$\begin{array}{l}\text { Smoking } \\
\text { Behavior }\end{array}$} \\
\hline $\begin{array}{l}\text { Yes } \\
\text { No }\end{array}$ & $\begin{array}{l}4 \\
26\end{array}$ & $\begin{array}{l}6,7 \\
43,3\end{array}$ & $\begin{array}{l}3 \\
27\end{array}$ & $\begin{array}{l}5,0 \\
45,0\end{array}$ & 1,000 & - & $(0,282<O R<6,796)$ \\
\hline \multicolumn{8}{|l|}{$\begin{array}{l}\text { Physical } \\
\text { Activities }\end{array}$} \\
\hline $\begin{array}{l}\text { Moderate } \\
\text { High }\end{array}$ & $\begin{array}{l}22 \\
8\end{array}$ & $\begin{array}{l}36,7 \\
13,3\end{array}$ & $\begin{array}{l}7 \\
23\end{array}$ & $\begin{array}{l}11,7 \\
38,3\end{array}$ & 0,000 & 9,036 & $(2,802<\mathrm{OR}<29,134)$ \\
\hline
\end{tabular}

The results of the analysis of the relationship between the attitudes of respondents about pulmonary TB disease with the occurrence of pulmonary TB-TB is known that $p=0.039$ which means $p<a$ $(0.05)$. These results describe that there is a significant relationship that is the attitude of respondents about pulmonary TB disease with the occurrence of pulmonary DM-TB. Odds Ratio value 3.455 $(1,191<O R<9,990)$. From the results of the OR calculation, the results of the study show that DM sufferers who have a negative attitude about pulmonary TB disease have a 3.455 times greater chance of developing pulmonary TB disease than DM sufferers who have a positive attitude about pulmonary TB disease. Notoatmodjo argues that attitude is a closed reaction because the stimulus involves emotional factors as well as the opinion factor in question, so the attitude is not an open reaction or action, even though the open reaction has the potential to tend to act (Notoatmodjo, 2010).

DM sufferers who tend to be negative include not agreeing to avoid using food equipment together with patients with pulmonary TB. It causes the use of food equipment that is too much so that the use of the same equipment can minimize the use of cooking utensils or food equipment. DM sufferers consider pulmonary TB disease it is not contagious and DM sufferers consider pulmonary TB disease to be a hereditary disease of their 
family members. DM sufferers also tend to disagree if environmental improvements are carried out such as by making ventilation that can help reduce the transmission of pulmonary TB disease because their home buildings coincide with the building of other people's houses or their neighbors and there is no cost for the construction of ventilation which makes DM sufferers reluctant to make repairs ventilation.

DM sufferers also tend to disagree to avoid sharing a room with pulmonary TB sufferers due to inadequate home area and limited bedroom space available in DM sufferers' homes. They assumed that it was enough to wear a mask to prevent transmission to other family members and not to spit carelessly in their bedroom. Only a small proportion of DM sufferers are willing to prepare a separate container that contains lisol to spit in DM sufferers' rooms. The positive attitudes of DM sufferers towards Tuberculosis are shown by agreeing to close the nose and mouth when there are other people or family members who cough or sneeze around them, but only a small proportion of DM sufferers know that this pulmonary TB disease is contagious through splash disease phlegm so that they do not have the awareness or willingness to prevent the transmission of pulmonary TB disease.

Some DM sufferers are less concerned about the condition or symptoms of the disease. Patients consider that symptoms of cough that are long enough are common so that sufferers do not try to seek treatment. Most sufferers treat the disease with drugs purchased by drug stores, but if it does not heal and get worse or there are symptoms of coughing up blood with almost one small glass of blood they end up seeking treatment at the hospital. This is due to the lack of funds for treatment so that respondents appear concerned about the amount of their treatment funds.

Patient attitude is one aspect that can affect health. The case group or pulmonary TB DM group mostly has a negative attitude towards pulmonary TB disease. The attitude of the patient directly affects the patient's actions. Pulmonary TB, including diseases that can be controlled or prevented by healthy living. Negative attitudes about pulmonary TB disease can influence DM sufferers in acting to minimize the risk of pulmonary TB.

Based on Table 1, respondents who had smoking behavior as much as 6.7\% experienced pulmonary TB and 5\% were not exposed to pulmonary TB, while respondents who did not have smoking behavior were $43.3 \%$ exposed to pulmonary TB and $45.0 \%$ were not exposed to pulmonary TB. The results of the analysis of the relationship of smoking behavior to the occurrence of pulmonary DM-TB using the Chi Square test obtained $p$ value 1,000 so that the value of $p>a$ (0.05) which indicates that there is no significant relationship between smoking behavior on the incidence of pulmonary DM-TB. This study found results where there was no significant relationship between smoking behavior carried out by people with DM with the incidence of pulmonary TB. This is due to the relatively small number of respondents who behave smoking that is $11.7 \%$ and the difference in the number of respondents who have smoking behavior between case group respondents and control group respondents is not too far that is at $6.7 \%$ and $5 \%$.

Respondents in this study were mostly respondents who behaved as smokers, and some male respondents did not have smoking behavior because they had stopped smoking behavior several years before being diagnosed with DM and had stopped smoking when they had been diagnosed with DM by the doctor. Only a small proportion of male respondents still have smoking behavior even though they spend one to two cigarettes in one day and not every day the respondent smokes. Most of the respondents in this study were respondents who had the behavior as passive smokers with a proportion of $63.3 \%$ greater than the proportion of non-smokers respondents at $36.7 \%$. They have the habit of being passive smokers when trading in the market more precisely next to other people who have smoking habits, and there are buyers who smoke next to them when they sell around. Some respondents claimed that there was one or several family members who behaved smoking in the house or around them.

The results shown in this study contradict the results of previous studies, where in that research stated that there was a relationship between smokers and 
the incidence of pulmonary $\mathrm{TB}$ in $\mathrm{DM}$ patients. Based on existing references, it is mentioned that the body's defense system can be weakened by smoking, making it possible to risk TB infection. Cigarettes are known to have a greater risk for active TB than non-smokers, thus one way to reduce the risk of TB is to stop consuming cigarettes .

Exposure to cigarette smoke reduces normal mucocillary function in clearing pathogens from the lungs and bronchi. Alveolar macrophages in smokers are more difficult to respond to harmful bacteria in the lungs. In addition, the immune system response is suppressed in people who smoke. Exposure to cigarette smoke causes the person to cough more frequently which might facilitate air circulation containing Mycobacterium tuberculosis from the lungs of smokers who are infected which can increase transmission of the spread of disease (Ardhi, Salam and Raharjo, 2014).

In Indonesia, there are two types of cigarettes, the most popular ones are kretek cigarettes and white cigarettes. Both types of cigarettes on the market can be either factory-made cigarettes or handmade cigarettes. Total sales of factory-made cigarettes in Indonesia in 2010 amounted to 180 million sticks. This number increased from $4.5 \%$ in 2009 (WHO, 2012).

Classification of data smokers is shown by the number of cigarettes smoked, can be divided into smokers who smoke less than 10 cigarettes per day are classified as light smokers, smokers who smoke 10-20 cigarettes per day are included in the category of moderate smokers, while smokers who smoke more than 20 cigarettes per day are included in the category of heavy smokers (Tisa $\mathrm{K}$, 2012). Based on Table 2, respondents who had a moderate level of activity were $36.7 \%$ affected by pulmonary TB and $11.7 \%$ were not exposed to pulmonary TB, while respondents who had a high level of activity were $13.3 \%$ affected by pulmonary TB and $38.3 \%$ were not affected Lung TB.

The results of the study of the relationship between physical activity and the incidence of pulmonary TB using the Chi Square test. The results of the assessment are $p$ value of 0,000 with a value of $a=0.05$. This can be interpreted that there is a significant relationship between physical activity and the incidence of pulmonary DM-TB. Odds Ratio obtained is equal to 9,036 $(2,802<0 R<29,134)$.

The OR results show that DM patients who have moderate levels of physical activity have a 9.036 times greater chance of developing pulmonary TB than DM patients who have high levels of physical activity. Physical activity can be interpreted where the body's movements by skeletal muscles that use energy. This lack is an independent risk factor for chronic illness, and is thought to cause death globally (Reed et al., 2013). Physical activity or exercise can have a direct effect with an increase in the process of muscle glucose recovery. This is because when exercising muscles take glucose stored, if glucose decreases the muscles take glucose from the blood. Automatically it can reduce blood glucose so that it can be a way to control blood glucose (Barnes, 2012). This study shows that there is a significant relationship of physical activity of people with DM with the occurrence of pulmonary TB. DM patients who have moderate activity levels have a 9.036 times greater chance of developing pulmonary TB than DM sufferers who have high levels of physical activity.

Most DM sufferers only have a job as shopkeepers, some respondents also do not have a job so the respondent has moderate physical activity that is only caring for and caring for grandchildren or babies without carrying or carrying him. Most respondents also have jobs as housewives with or without washing clothes because they use washing machines or have been done by other family members such as children and grandchildren. Doing moderate physical activity regularly affects the decrease in mortality. The decline in these numbers is $45-70 \%$ in patients with type 2 diabetes, but it can also reduce HbA1c levels. These conditions can prevent complications. Perform physical activity in a minimum span of 150 minutes every week such as aerobic exercise and endurance training. The combination of the two can be done, it is related to the decrease in HbA1c levels in the body of patients with type 2 DM (Umpierre et al., 2011).

Body tissue in resting conditions requires insulin for glucose absorption, whereas in active conditions the body is 
not accompanied by an increase in insulin levels despite an increase in glucose requirements. That is because when a person is active there is also an increase in insulin receptor sensitivity. The main problem experienced by sufferers of type 2 diabetes is insulin resistance which causes the existing glucose can not enter the cell. If someone does an active activity, there will be muscle contraction where this condition makes it easier for glucose to enter the cell. This can be interpreted that the activity of a person for physical exercise can reduce insulin resistance where the condition can reduce blood sugar levels (Soegondo, Soewondo and Subekti, 2011). Physical activity or exercise has great benefits for people with DM. These benefits include lowering blood glucose levels, preventing weight gain, overcoming complications, overcoming blood lipid disorders and increasing blood pressure (Soegondo, Soewondo and Subekti, 2011).

\section{CONCLUSION}

The conclusion in this study is that there is a significant relationship between attitudes towards the occurrence of pulmonary TB in patients with DM, there is a significant relationship between physical activity on the occurrence of pulmonary TB in DM patients, and there is no significant relationship between smoking behavior with the occurrence of pulmonary TB in DM sufferers.

\section{REFERENCES}

Ardhi, T. J., Salam, A. and Raharjo, W. (2014) 'Gambaran Hasil Pemeriksaan Sputum pada Pasien TB Paru yang Merokok dan Tidak Merokok di Wilayah Kerja Puskesmas Kampung Dalam Kecamatan Pontianak Timur Tahun 2012-2013', Naskah Publikasi.

Badan Penelitian dan Pengembangan Kesehatan (2013) Riset Kesehatan Dasar (RISKESDAS) 2013, Laporan Nasional 2013. Jakarta. doi: 1 Desember 2013.

Barnes, D. . (2012) Program Olahraga Diabetes. Yogyakarta: Citra Aji Parama.

Dinkes Kota Surabaya (2015) Profil
Kesehatan Kota Surabaya 2015. Surabaya: Dinas Kesehatan Kota Surabaya.

Kemenkes RI (2013) Profil Kesehatan Indonesia $2012 . \quad J a k a r t a:$ Kementerian Kesehatan Republik Indonesia.

Notoatmodjo, S. (2010) Promosi Kesehatan Teori \& Aplikasi. Jakarta: Rineka Cipta.

Reed, G. W. et al. (2013) 'Impact of Diabetes and Smoking on Mortality in Tuberculosis', PLOS ONE, 8(2), pp. 1-8. doi: 10.1371 /journal.pone.0058044.

Soegondo, S., Soewondo, P. and Subekti, I. (2011) Penatalaksanaan Diabetes Melitus Terpadu : Sebagai Panduan Penatalaksanaan Diabetes Melitus bagi Dokter maupun Edukator Diabetes. Jakarta: Fakultas Kedokteran Universitas Indonesia.

Tisa K, A. N. (2012) 'Hubungan Antara Kebiasaan Merokok Dengan Tekanan Darah Meningkat Karyawan Laki-Laki Di Nasmoco Semarang', Jurnal Kesehatan Masyarakat, 1(2), pp. 241-250. Available at: https: / /www.neliti.com/publicati ons/18783/hubungan-antarakebiasaan-merokok-dengantekanan-darah-meningkatkaryawan-laki-l.

Umpierre, D. et al. (2011) 'Physical Activity Advice Only or Structured With HbA 1c Levels in Type 2 Diabetes. A Systematic Review and Meta-analysis', JAMA: the journal of the American Medical Association, 305(17), pp. 17901799. Available at: https://jamanetwork.com/journa ls/jama/fullarticle/899553.

WHO (2012) Global Tuberculosis Report 2012. Geneva: World Health Organization. Available at: http: / /apps.who.int/medicinedoc s/en/m/abstract/Js19908en/.

WHO (2014) Global Tuberculosis Report 2014. Geneva: World Health Organization. Available at: http: / /apps.who.int/medicinedoc s/en/m/abstract/Js21634en/.

WHO (2015) Global Tuberculosis Report 2015. 20th edn, World Health Organization. 20th edn. Geneva: World Health Organization. doi: 
162 Jurnal Promkes: The Indonesian Journal of Health promotion and Health Education Vol. 7 No. 2 Desember 2019 : 156 - 162, doi: 10.20473/jpk.V7.12.2019.156-162

$10.1177 / 1942602 \times 17698487$.

Wijaya, I. (2015) 'Tuberkulosis Paru pada
Penderita Diabetes Mellitus', Cermin Dunia Kedokteran, 42(6). 